\title{
日本ゴム協会創立50周年記念式典
}

\section{祝 辞}

本日ここに，社団法人日本ゴム協会創立 50 周年記念式典が挙行されるに当たり，ひとことお祝いのこ 上ばを申し述べます。

貴協会は，昭和 3 年創立以来時代の要請に即応しつつ今日まで，ゴムに関連する学術研究の発展と技 術の振興に寄与され多大な成果を挙げられるとともに産業の発展, 文化の向上ひいては学術の国際交流 に貢献して来られました.

このたび創立50周年を迎えられ盛大な式典が挙行されますことは，歴代の代表者を始め会員各位のた ゆみない研鑽と協力の賜物であり，ここに深甚なる敬意を表する次第であります。

今日, 我が国は科学技術の飛躍的な発展を基盤として高度工業化社会の一員に成長するに至り, 著し い産業の発展と国民生活の向上とは世界各国の注目するところとなりました．反面資源の節約再利用及 び公害問題など幾多の解決すべき新たな課題をかかえていることも事実であります.

資源の豊かでない我が国においては，今後これからの課題の解決に全力をあげて取り組むべき時であ りますが，ゴムに関連する学術及び技術の分野におきましても，ゴム固形廃棄物の再資源化やゴム加工 製品の耐熱化のための研究開発，更に安全無公害な熱可塑性ゴムの加工技術の向上など，社会生活の進 歩と多様化に伴う新しい研究課題に関し, 広い社会的視野に立った積極的な研究開発が切に望まれると ころであり，貴協会の果される役割も一層重要性を増すものと思われます。

このような時に際し，貴協会が創立50周年を記念してここに盛大な式典及び各種行事を挙行され，新 たな展望の下に今後一層の発展を期されることは，誠に意義深いことと存じます.

本日の式典に当たり，協会創立以来の輝かしい業績を称え，今日の発展を禹心よりお祝い申し上げを すとともに，貴協会が今後ともゴムに関連する学術研究の発展と技術の振興に寄与されますよう希望し て，お祝いの言葉といたします。

昭和 53 年 5 月 17 日

\section{文部大臣 砂 田 重 民}

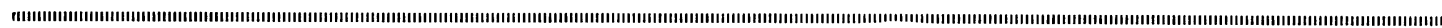

\section{祝 辞}

日本ゴム協会創立50周年記念式典に当たり，一言お祝いの言葉を申しあげます。

顧みますと，貴会はゴムに関連する学術及び産業の進歩発達を図り，文化の向上に寄与することを目 的として，昭和 3 年に創立されて以来，今日まで我が国ゴム産業の発展に努めてこられ，今日のゴム産 業の繁栄をもたらすに大いなる貢献をされました.

貴会が，我が国におけるゴムに関連する唯一の学術団体として学界及び産業界に寄与した業績は，枚 挙にいとまがありません，特に，当時の商工省の奨めにより貴会に昭和16年に設置された日本ゴム工業 技術員会においては，今日までゴム工業用諸資材の合理的利用方法及び増産に関する技術的研究に関す る指導をされ，ゴム製品の品質改良及び生産技術の向上に寄与してこられました。また，ゴム工業関係 の日本工業規格の制定改正に当たっては，多大の貢献をしてきておられます。これらは，歴代会長並び に会員各位の御努力によるものと，心から敬意を表するものであります。 
現在，我が国をとりまく経済情勢は極めて厳しいものがあり，我が国ゴム工業も困難な時期に直面し ておりますが，貴会の会員各位におかれましては，この輝かしい伝統を受け継がれ，新しい学理の探究 と新技術の開発に，今後より一層の努力と研鑽を重ねられ，この難局に対処されますことを期待申し上 げます。

最後に, 貴会が今後とも我が国ゴム工業のみならず, 世界のゴム工業の発展に貢献されることを祈念 いたしまして，私のお祝いの言葉とさせていただきます．

昭和53年 5 月 17 日

\section{通商産業大臣 河 本 敏 夫}

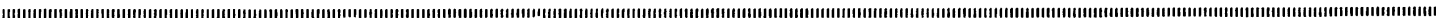

\section{祝 辞}

本日の記念式典に当たり，ゴム工業界を代表してお慶びを申しあげる機会を得ましたことは, 誠に光 栄に存じます.

我が国のゴム工業は，この半世紀の間に量的にも質的にも目覚ましい発展を遂げましたが，この進歩 と発展はゴムに関する基礎学理の研究と，これを実地に応用する技術の開発に負うところが大きいとは 改めて申しあげるまでもありません。

日本ゴム協会は，創立以来50年の歳月を重ねられ，その間に数々の有意義な活動を展開され，我が国 のゴム工業の発展に大いなる貢献をされるとともに，その組織を通じて会員相互の啓発と幅広い連帯を 築きあげられ，その業績は高く評価されるべきであると信じます．

私どもが住む社会は，時代とともに環境が変転し，これに伴って人々のニーズもまた変化し，私ども は常にこれに対応して前進し，活動することを求められております。

日本ゴム協会が光輝ある50周年を迎えられました機会に, 古き良き伝統のもとに，新しい時代に適応 した活動を展開され，単に国内のみならず世界のゴム協会として，今後ますます御発展を遂げられるこ とを期待いたしまして，祝辞といたします。

昭和53年 5 月 17 日

日本ゴム工業会

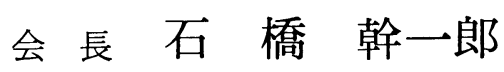

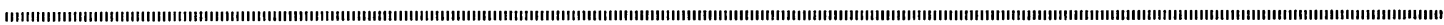

\section{祝 辞}

社団法人日本ゴム協会は, 本日創立 50 周年の栄ある式典を挙行せられるに当たり, 社団法人日本化学 会は心より御祝いを申しあげます。

日本ゴム協会は，昭和 3 年に創立せられ，ゴム科学並びにゴム工業の発展に多大の貢献をして来られ ました．50年前は我が国のゴム科学及びゴム工業は他の分野と同様に未だ幼年期にありましたが，いち 早く協会を成立され，その育成に努力せられ，また戦時中には懸命の努力をもって国家のために活躍さ れました，戦後においても他の産業にさきがけて復興に努力せられ，また石油化学工業の一役として合 
成ゴム工業は驚異的発展を遂げられました。このように貴協会は常に活力をもって学界及び業界をリー ドしてこられましたことは誠に敬服に值するものであります.

我が国では，化学及び化学工業の分野に30以上の学協会があり，それぞれ活発に活動しておられます が，学界及び業界の協力について貴学会の挙げられました成果は特に賞賛されるべきものと思います.

日本の化学工業, 特に高分子産業の前途については, 必ずしも楽観を許すものばかりではありません が, 貴学会が過去において示された旺盛な活力によって益々発展されることは疑いのないものと信じま す、日本の工業が戦後技術導入と技術改良により飛躍的発展を遂げたことは周知の事実でありますが, この時代も終り, 今や省資源, 省エネルギーの時代に入り自らの発明開発が強く要請されることになり ました. この時代に当り, 学界と業界の一層の連結が必要であるとともに関連学協会の学際的協力が一 段と重要になって参りました. 貴協会の今までのたゆまぬ御努力に敬意を表するとともに, 今後の御尽 カに期待するものであります.

50年の輝しい歷史の金字塔を打ち建てられた貴学会が, 次の新しい将来を迎えられる本日の式典を衰 心よりお祝い申し上げる次第であります.

昭和 53 年 5 月 17 日

社団法人 日本化学会

会長古川淳二

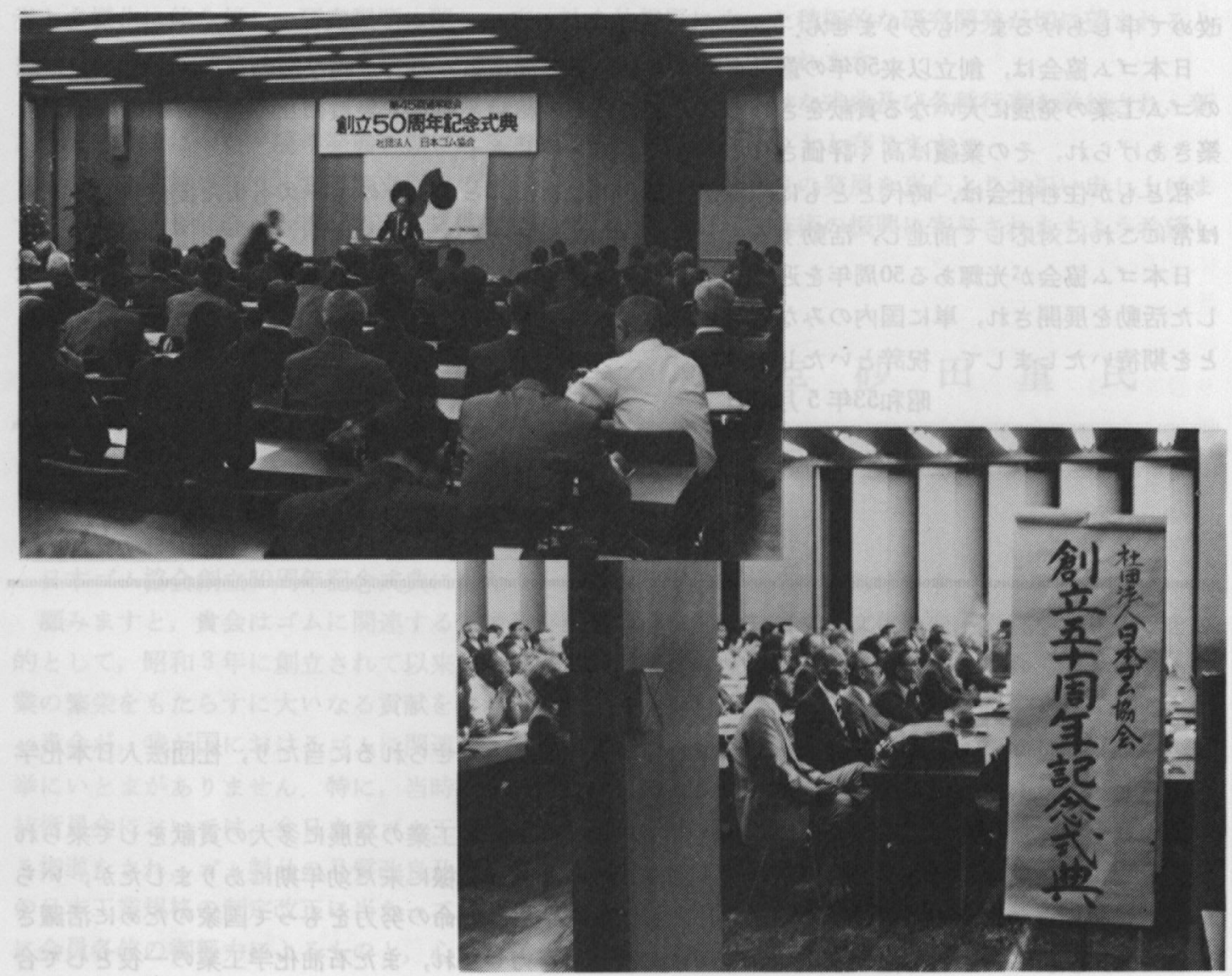




\section{Godden Suldileo

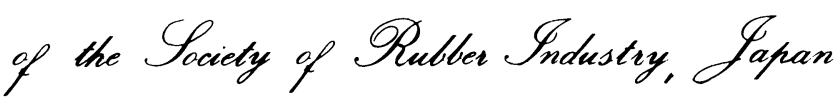

Deutsche Kautschuk-Gesellschaft and its members present their compliments to their Japanese colleagues and congratulate them most heartily on their Golden Jubilee.

The Society of Rubber Industry, Japan, is known as the only authorized academic society of Japanese rubber chemists and technicians. Obviously its aims are similar to ours, i.e. encouraging technological progress and offering scientists and technicians a forum for discussions and reports on their studies.

The Japanese rubber industry has known an exciting rise in the past few decades. Japan's synthetic rubber production, for instance, is second only to that of the United States of America. Its production capacity was three times ours in 1976. Japanese exports have been rising steadily in recent years.

This progress means a challenge to the German rubber industry, and the natural consequence is keen competition. The more friendly aspect of this competition lies in the field of research and development. The success that our Japanese colleagues have obtained in this domain is most remarkable. We may congratulate them on the excellent work they have done.

Scientific progress, internationally achieved, means another step forward in the history of mankind. Both our societies consider it their supreme aim and object to promote this progress in establishing and deepening contacts all over the world.

We hope that the contacts existing between our organizations will continue to improve, and we wish our Japanese colleagues good luck and success for times to come.

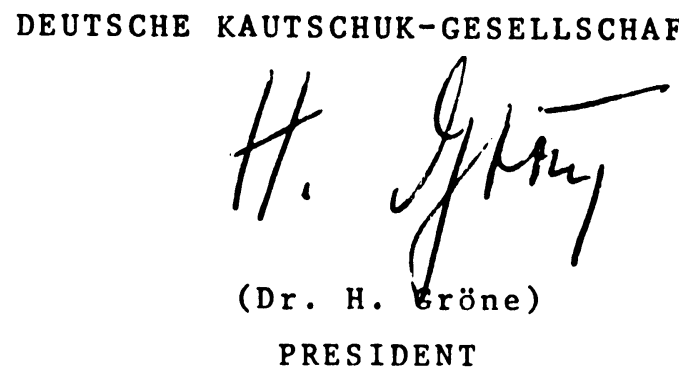


Gentlemen,

The "Association Française des Ingénieurs du Caoutchouc et des Plastiques" (AFICEP) is very pleased to congratulate the Society of Rubber Industry, Japan, for the occasion of its golden jubilee.

Our Associations have the same purpose : the opportunity of contacts between people concerned by the Rubber Industry, and a better knowledge of Rubber Technology through the organisation of scientific or technical meetings.

The Society of Rubber Industry, Japan, made a large effort in that respect and the AFICEP is wishing it a long life for the benefit of all its members.

"Association Française des Ingénieurs du Caoutchouc et des Plastiques"

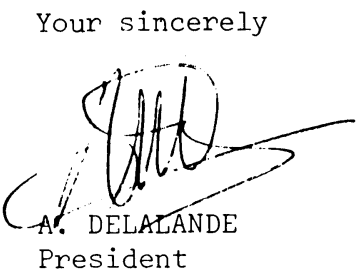

The Rubber Division of the American Chemical Society takes great pleasure in congratulating The Society of Rubber Industry, Japan on your golden jubilee in 1978. Our societies have common purposes concerned primarily with the advancement of science and technology of rubber, rubberlike materials, and rubber products, and with increasing the professional competence of people associated with these industries.

Al1 nine of the speakers from North America and our Rubber Division representative who participated in your Tokyo International Rubber Conference October 14-17, 1975, highly praised the efficiency, quality, and gracious hospitality of The Society of Rubber Industry, Japan. Their experiences were most helpful in assisting us to host the 1976 San Francisco International Rubber Conference.

Rubber science and technology is highly interdependent world wide. Many of our scientists will be meeting together again April 1-6, 1979 at the ACS/CSJ Chemical Congress in Honolulu.

Congratulations again on your society's many major accomplishments during your first fifty years. We wish The Society of Rubber Industry, Japan, all possible continued success.

Sincere $1 y$,

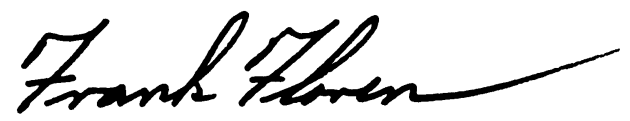

Rubber Division

American Chemical Society

F. B. F1oren

Chairman 
As the President of the Plastics and Rubber Institute London, I have great pleasure in sending you our congratulations and best wishes for your Golden Jubilee which you are celebrating on May 17th, 1978 in Tokyo.

The Rubber Industry has contributed a great deal to the well being and comfort of man in the last Century and societies such as the Society of Rubber Industry, Japan and the Plastics and Rubber Institute play an important part in communicating knowledge and encouraging the development of the skills of their members.

On the occasion of a Jubilee it is important to recognise the advances that have been made in the past and also look forward to strengthening our organisations for the future.

The Plastics and Pubber Institute would like to convey to all members of the Society of Rubber Industry, Japan their good wishes for future years.

\section{Yours sincerely,}

The Plastics and

Rubber Institute

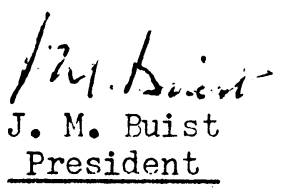

President

The Management and the Scientific Council of the Rubber and Plastics Technology Research Institute at Gottwaldov wish to extend to the Director and all Society members their most sincere congratulations on the Golden Jubilee of the Society of Rubber Industry in Japan, whose research work makes a great contribution to the development of the world rubber science and technology.

We wish you all every succes in your further beneficial work.

Rubber and Plast1cs Technology
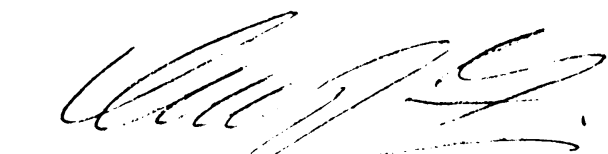

Dr. Zdenğk s ì ě 1 Ý Fiesearch Institute Director

\section{CZECHOSLOVAKIA}


Time is infinite only in the abstract. Measured in man's limited life span or in the growth of an organisation, fifty years is a most significant milestone. It therefore gives me great pleasure to congratulate the Society of Rubber Industry of Japan on the occasion of its Golden Jubilee. May I wish it ever increasing vigour and success.

And yet, success cannot be measured in terms of one's own progress. In an ever diminishing world, success can be real only if its fruits are shared by the many. Isolated victories or advances are but egocentric achievements and of little consequence to the world at large.

I have therefore no doubts that the Society will continue to appreciate the overall scene affecting the natural rubber producers and consumers and will organise its activities to ensure better understanding all round and pramote the greater usage of rubber.

Judging from the wide-ranging activities of the Society, there is every reason to congratulate it on its past efforts towards the enhancement of knowledge related to rubber, natural and synthetic. When knowledge is advancing rapidly and technological innovations continuing to increase, there is no gainsaying about the greater future for rubber as an industrial performance material. I am confident that the Society will continue to take advantage of this situation, and as in the past fifty years, contribute to the fund of information on rubber.

In this may it succeed fifty folds greater than in the last fifty years.

Yours sincerely,

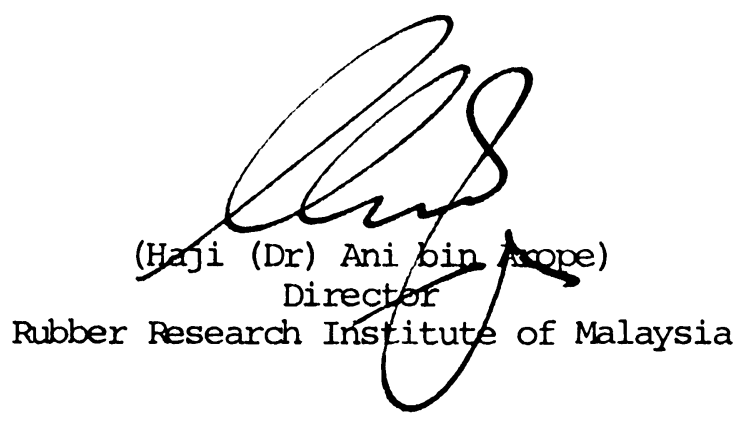

